\title{
Peningkatan Keterampilan Analisis Data Deskriptif dan Inferensial melalui Pelatihan Microsoft Excel dan Aplikasi SPSS
}

\author{
Melkianus Suluh $^{1 *}$, Yuliana Sesi Bitu² \\ ${ }^{1}$ Program Studi Pendidikan Fisika, STKIP Weetebula, Sumba Barat Daya-NTT, Indonesia; \\ ${ }^{2}$ Program Studi Pendidikan Bahasa Indonesia, STKIP Weetebula, Sumba Barat Daya-NTT, Indonesia.
}

https://doi.org/10.29303/jpmpi.v3i2.934

Sitasi: Suluh, M \& Nitu, Y. S. (2021). Peningkatan Keterampilan Analisis Data Deskriptif dan Inferensial melalui Pelatihan Microsoft Excel dan Aplikasi SPSS. Jurnal Pengabdian Magister Pendidikan IPA 4(4)

\section{Article history}

Received: 19 Oktober 2921

Revised: 30 Oktober 2021

Accepted: 30 November 2021

*Corresponding Author:

Melkianus Suluh, Program

Studi Pendidikan Fisika,

STKIP Weetebula, Sumba

Barat Daya-NTT, Indonesia;

Email: $\underline{\text { smelkieinstein@gmail.com }}$

\begin{abstract}
Abstrak: Kegiatan pengabdian ini memiliki tiga tujuan, yaitu, 1) agar mahasiswa memahami konsep penelitian deskriptif dan inferensial, 2) agar mahasiswa mampu mengolah data deskripif dengan memanfaatkan Microsoft excel, 3) agar mahasiswa mampu mengolah data inferensial dengan menggunakan aplikasi SPSS. Subyek pelatihan dalam kegiatan pengabdian ini adalah mahasiswa semester 7 yang berjumlah 60orang. Subyek pengabdian tersebut tersebar pada empat program studi yang ada di STKIP Weetebula, meliputi Program Studi Pendidikan Fisika, Program Studi Pendidikan Matematika, Program Studi Pendidikan Bahasa Indonesia, dan Program Studi Pendidikan Guru Sekolah Dasar. Untuk meningkatkan efektifitas pelatihan, subyek pengabdian di bagi menjadi dua kelompok. Masing-masing kelompok mengikuti 3 kali kegiatan pelatihan. Metode yang digunakan dalam pelatihan adalah ceramah, tanya jawab dan unjuk kerja. Materi yang dibahas meliputi, pada pertemuan pertama membahas materi konsep penelitian deskriptif dan penelitian inferensial. Materi pelatihan yang diberikan pada pertemuan kedua adalah pengolahan data deskritif dengan Microsoft excel. Sementara itu, materi pertemuan ketiga adalah pengolahan data dengan program SPSS. Hasil pengabdian menunjukkan bahwa 1) Mahasiswa semakin memahami konsep penelitian deskriptif dan inferensial. 2) Mahasiswa memahami teknik analisis data deskripif dan mampu mengolah data deskriptif dengan memanfaatkan Microsoft excel. 3) Mahasiswa semakin memahami teknik analisis data inferensial dan mampu mengolah data inferensial dengan memanfaatkan aplikasi SPSS. Hasil lain yang diperoleh adalah subyek pengabdian menunjukkan sikap antusiasme dan partisipatif selama kegiatan pelatihan.
\end{abstract}

Kata Kunci: Analisis Data, Statistik Deskriptif, Statistik Inferensial, Microsoft excel, SPSS

\section{Pendahuluan}

Perkembangan teknologi komunikasi dan informasi tidak serta merta meningkatkan pengetahuan dan keterampilan mahasiswa untuk memanfaatkan dan mengaplikasikannya. Terdapat banyak aplikasi yang sudah seharusnya dikuasai mahasiswa untuk mendukung penyelesaian studi di perguruan tinggi, namun kenyataanya masih terdapat banyak mahasiswa yang kurang mengetahui aplikasi dan program-program yang sedianya akan membnatu tugas mereka dalam proses perkuliahan. Ketidak tahuan ini berdampak pada tidak dimanfaatkanya program-program tersebut secara maksimal, baik program bawaan computer maupun aplikasi atau program yang perlu ditambahkan.

Mahasiswa dalam upaya menyelesaikan studi telah banyak dibekali dengan beragam pengetahuan dan keterampilan yang sekiranya akan bermanfaat dalam dunia kerja. Salah satunya adalah keterampilan untuk mengoperasikan komputer dan menguasai dasar-dasar dari program Microsoft. Komputer pada dasarnya merupakan salah satu media elektronik yang memudahkan aktivitas manusia data, menyimpan informasi (data storage) dengan praktis dan efisien (Permana dan Mahameruaji, 2019). Berkaiatan dengan kebutuhan dan tuntutan akan penguasaan komputer, 
Helaluddin (2019) mengemukakan bahwa dengan menguasai teknologi komputer, merupakan salah satu bentuk aplikasi yang dilakukan untuk mengikuti dan mengimbangi perkembangan zaman. Sehingga dapat dikatakan bahwa kebutuhan akan penguasaan komputer pada jaman sekarang adalah sebuah kebutuhan dan keharusan. Pada berbagai lembaga pendidikan tinggi, khususnya STKIP Weeebula berusaha sedari awal mengenalkan komputer kepada mahasiswa dengan menempatkan mata kuliah komputer pada semester awal. Pemilihan mata kuliah ini diajarkan pada semester awal disebabkan terdapat banyak mahasiswa yang tidak memiliki pengetahuan dasar terhadap komputer. Dosen pengampuh mata kuliah harus memulai perkuliahan komputer dari hal-hal yang sangat sederhana. Tantangan ini hampir dihadapi oleh setiap program studi yang berada dilingkup STKIP Weetebula. Kondisi perkuliaan tersebut secara tidak langsung menghambat beberapa mahasiswa yang telah memiliki pengetahuan dasar komputer untuk semakin meningkatkan pengetahuan dan keterampilannya. Untuk memfasilitasi mahasiswa-mahasiswa tersebut, dan memotivasi mahasiswa dengan keterampilan yang kurang, beberapa program studi (Program Studi Pendidikan Fisika dan Program Studi Pendidikan Matematika) menyediakan mata kuliah komputer lanjut. Harapannya akan semakin meningkatkan pengetahuan dan keterampilan mahasiswa dalam mengoperasikan komputer serta mahasiswa dapat menguasai beberapa aplikasi yang sekiranya bermanfaat bagi mahasiswa saat berada di dunia kerja. Namun, kenyataannya masih banyak mahasiswa dengan keterampilan penguasaan komputer yang masih rendah. Hal ini disebabkan oleh keterbatasan jam perkuliahan, fokus perhatian dosen yang terbagi dengan jumlah mahasiswa yang banyak, juga keadaan ekonomi mahasiswa yang tidak memungkinkan mahasiswa memiliki komputer. Persoalan bahwa mahasiswa tidak memiliki komputer pribadi sangat berpengaruh terhadap pengembangan pengetahuan dan keterampilan mahasiswa.

Rendahnya penguasaan komputer, penguasaan program dan aplikasi komputer, berdampak pada lemahnya kamampuan mahasiswa dalam melakukan analisis data hasil penelitian dengan memanfaatakan komputer. Mahasiswa masih menggunakan perhitungan manual, hal ini berakibat lambatnya mahasiswa melakukan kegiatan pengolahan dan analisis data hasil penelitian. permasalahan masih rendahnya kemampuan mahasiswa dalam mengolah data juga diungkap oleh Zainal Putra, dkk (2018), Fauziah, dkk (2019) serta Febrilia dan Setyawati (2020) bahwa masih ditemukan mahasiswa yang tidak paham mengenai cara pengolahan data, sehingga perlu dilakukan penelitian cara mengoperasikan program SPSS, menginput dan memproses data serta membaca output atau menginterpretasikan.

Berdasarkan permasalahan lemahnya kemampuan mahasiswa dalam menggunaan komputer dan dalam melakukan analisis data hasil penelitian, diperlukan suatu kegiatan berupa pelatihan komputer yang difokuskan dapa pemanfaatan Microsoft excel sebagai alat bantu pengolahan data. Selain itu, untuk memudahkan melakukan analisis data hasil penelitian, maka mahasiswa perlu diperkenalkan aplikasi spss dari dasar, pengolahan data, hingga pada tahap analisis data.

Program excel adalah salah satu bagian dari program Microsoft yang memberikan kemudahan untuk melakukan pengolahan data karena menggunakan prinsip data base. Excel memberikan kemudahan pengolahan data karena database yang tersedia tersusun dalam bentuk kolom dan baris pada setiap sheet. Menurut Wicaksono (2015), dengan menguasai excel, pengolahan data dapat dilakukan dengan mudah dan cepat, sehingga akan meningkatkan produktivitas kerja. Dengan memperhatikan prinsip kerja dari microsoft excel, mahasiswa akan mudah menggunakan program ini karena berbasis pada rumus matematika dan logika matematika. Sedangkan program SPSS adalah program yang bekerja dengan mengolah data yang tersedia pada database tanpa perlu memasukan rumus-rumus matematika dan logika matematika. Program ini akan sangat memudahkan bila mahasiwa telah mengetahui jenis data apa yang akan diolah dengan memilih kalimat perintah yang telah disediakan oleh program spss.

Berdasarkan latar belakang tersebut, kegiatan pengabdian ini bertujuan untuk 1) memberikan pemahaman kepada mahasiswa tentang konsep penelitian deskriptif dan inferensial, 2) memberikan pelatihan kepada mahassiwa agar mampu mengolah data deskripif dengan memanfaatkan Microsoft excel, dan 3) memberikan pelatihan kepada maahsiswa agar mampu mengolah data inferensial dengan menggunakan aplikasi SPSS.

\section{Metode}

Subyek pelatihan adalah mahasiswa Program Studi Pendidikan Fisika, Pendidikan Matematika, Pendidikan Bahasa Indonesia, dan Pendidikan Guru Sekolah Dasar STKIP Weetebula 
yang berjulah 60 orang. Subyek Pengabdian kemudian dibagi menjadi 2 kelompok. Masingmasing kelompok mendapatkan 3 kali pelatihan. Kegiatan Pelatihan dilaksanakan setipa hari sabtu pada pada bulan desember 2020.

Materi Pelatihan adalah konsep penelitian deskriptif dan penelitian inferensial, Pemanfaatan program microsoft excel dalam melakukan analisis data deskriptif, dan penggunaaan aplikasi SPSS dalam menganalisis data penelitian inferensial. Adapun mekanisme pelaksanaan pengabdian adalah

1. Memberikan informasi kepada Ketua Program Studi terkait pelaksanaan pengabdian masyarakat pelatihan analisis data kepada mahaiswa semester 7 dengan kegiatan pendaftaran dilakukan secara online melalui google form, diutamakan yang memiliki laptop pribadi. Anjuran membawa laptop didasarkan pada tidak dapat digunakannya Laboratorium Komputer di masa Pandemi Covid-19.

2. Pengabdi kemudian meminta kesediaan Ketua Program studi untuk meneruskan formulir pendaftaan kepada mahasiswa masing-masing program studi.

3. Pada formulir pendaftaran juga dilengkapi tautan agar mahassiwa dapat bergabung pada group whatsaap.

4. Bersama mahasiswa calon peserta pelatihan kemudian disepakati waktu pelaksanaan kegiatan pelatihan.

5. Membagi mahasiswa menjadi 2 kelompok dengan masing-masing kelompok terdiri dari 30 orang peserta. Pembatasan jumlah peserta karena kegiatan pengabdian dilaksanakan di masa pandemic covid-19.

\section{Hasil dan Pembahasan}

Kegiatan pelatihan pemanfaatan Microsoft excel dan aplikasi SPSS secara umum berjalan dengan lancar dan baik. Peserta pelatihan merupakan mahasiswa semester VII yang berasal dari empat program studi yang terdapat di STKIP Weetebula, yaitu Program Studi Pendidikan Fisika, Program Studi Pendidkan Matematika, Program Studi Pendidikan Bahasa Indonesia, dan Program Studi Pendidikan Guru Sekolah Dasar. Tempat yang digunakna adalah Gedung R1. Pemilihan penggunaan Gedung R1 karena pada Gedung tersebut menggunakan listrik tenaga surya, sehingga menjamin terlaksananya kegiatan pelatihan tanpa adanya gangguan teknis berupa listrik padam. Sebelum dilaksanakannya kegiatan pelatihan, mahasiswa peserta pelatihan diberi modul pelatihan, baik hard copy maupun soft copy.
Pada pertemuan pertama, untuk setiap kelompok, disampaikan materi tentang teknis analisis data secara deskriptif dan secara inferensial. Tujuannya adalah memberikan gambaran kepada mahasiswa perbedaan kedua teknik analisis data tersebut, serta memberikan gambaran kelebihan dan kekurangan dari kedua jenis penelitian yang menggunakan teknik analisis data deskriptif dan inferensial.

Pertemuan kedua diisi dengan pelatihan analisis data deskriptif menggunakan Microsoft Excel. Sebelum dilaksanakannya kegiatan pelatihan, mahasiswa peserta pelatihan mendapatkan file excel yang berisi data-data yang akan di analisis. Tujuannya adalah mahasiswa dapat mempelajari terlebih dahulu dengan mengikuti tahapan yang terdapa dalam modul yang telah dibagikan sebelumya. Tujuan lain adalah dengan menggunakan data yang sama, maka mahasiswa akan berupaya agar data hasil analisis data yang mereka lakukan sama. Kendala yang dihadapi pada pertemuan ini adalah masih terdapat banyak mahasiswa yang kurang mampu mengoperasikan Microsoft excel dengan baik, sehingga disela-sela kegiatan pelatihan analisis data, dilakukan pendampingan pengoperasian Microsoft excel. Hasil dari kegiatan ini adalah mahasiswa semakin paham bahwa penilitian analisis data penelitian deskriptif dapat dilakukan dengan Microsoft excel, serta mahasiswa semakin terampil mengoperasikan microsotf excel. Kegiatan atau pertemuan kedua ini juga dilaksanakan dengan membagi mahasiwa kedalam kedua kelompok.

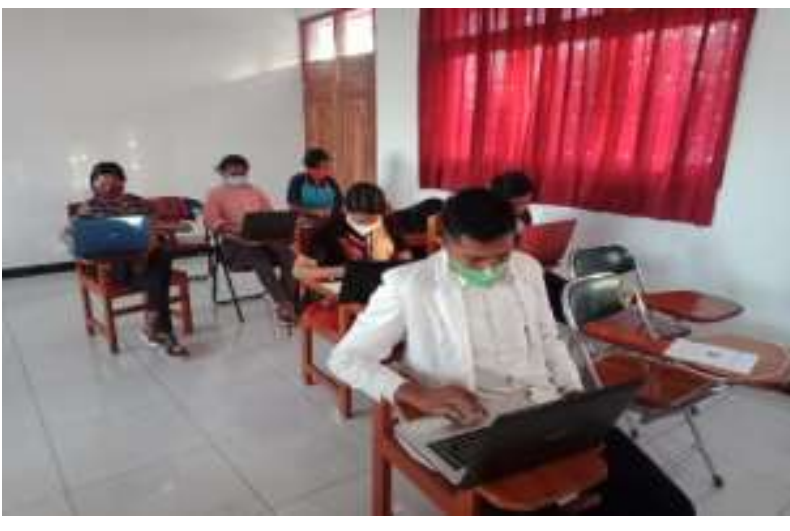

Pertemuan ketiga adalah pelatihan pemanfaatan program SPSS. Seperti halnya pada pertemuan kedua, pada pertemuan ini, diawali dengan membagikan materi pelatihan berupa sekumpulan data yang harus di olah mahasiswa. Tujuannya juga adalah agar dalam proses pelatihan analisis data, mahasiswa akan mendapatkan hasil 
yang sama, serta mempermudah penjelasan terkait dengan inteprestasi data.

Kegiatan pada pertemuan dimulai dengan menyampaikan kelebihan analisis data dengan program SPSS. Kegiatan kemudian dilanjutkan dengan mengenalkan tampilan dari SPSS yaitu data sheet yang terdiri dari dan data view dan variabel view.

Gambar 1. Laman data view

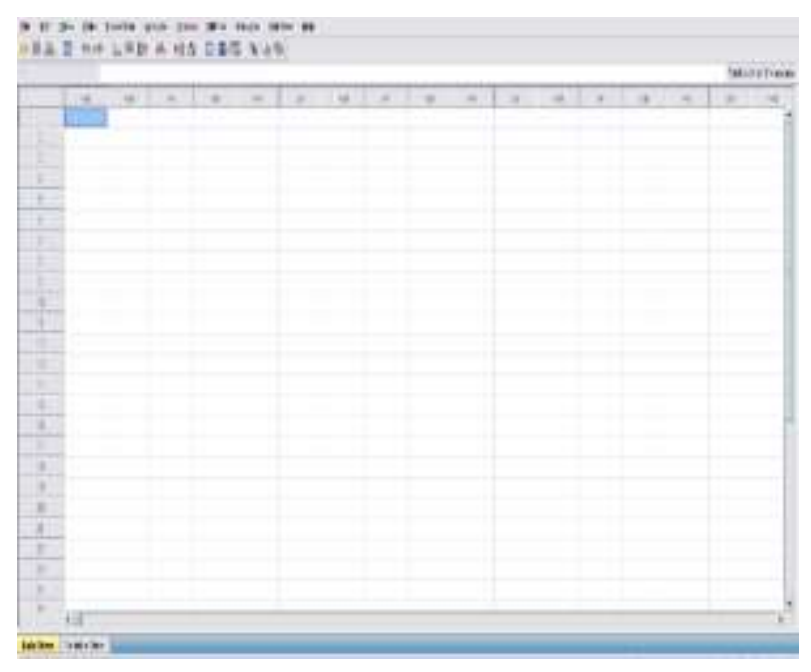

Lanngkah selanjutnya adalah memberikan penjelasan singkat mengenai laman data sheet, serta memberikan arahan tahapan-tahapan menginput data. Pengabdi memberikan beberapa 30 data yang sama yang harus diinput oleh mahasiswa. Setelah mengisis data view, mahasiswa diarahkan untuk mengisi kolom variabel viewdengan tujuan untuk membedakan setiap kolom dan variabel yang akan dianalisi seperti gambar 2 .

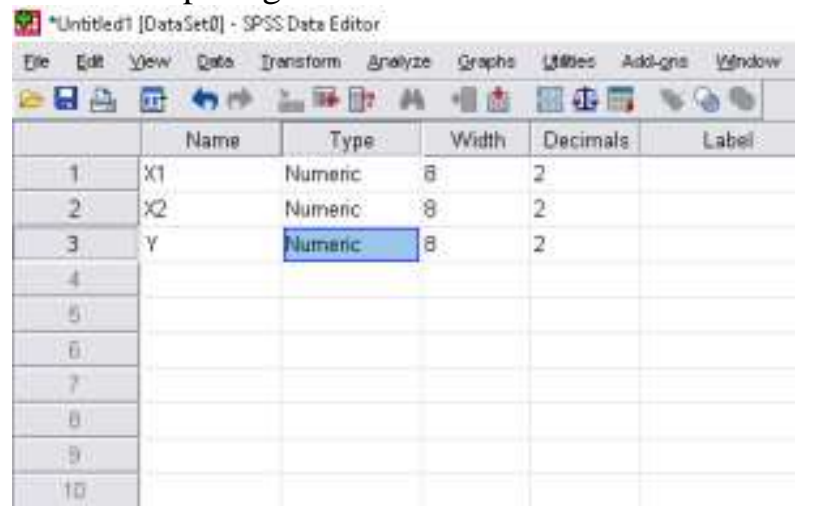

Gambar 2. Laman variabel view

Kendala yang dihadapi pada pertemuan ini adalah, masih rendahnya kemampuan statistik dari mahasiswa. Masih rendahnya kemampuan mahasiswa dalam membaca data menyebabkan pertemuan pelatihan analisis data dengan spss yang direncanakan dilaksanakan dalam satu pertemuan harus dilaksanakan dalam dua pertemuan.

Berdasarkan hasil pengamatan yang dilakukan selama kegiatan pengabdian, mahasiswa peserta kegiatan sangat antusias dalam mengikuti pelatihan. Hasil pelatihan ini memberikan pengetahuan dasar bagaimana mahasiswa menginput data penelitian.

Kegiatan pengabdian ini sebenarnya belum benar-benar mencapai tujuan yakni memberikan pengetahuan yang cukup luas dan mendalam hingga pada tahap inteprestasi data. Namun demikian, peserta pelatihan telah memiliki pengalaman melakukan penginputan data, hingga pemilihan teknik analisis yang sesuai dengan arah penelitian.

\section{Rekomendasi Rencana Tindak Lanjut}

Berdasarkan evaluasi dan monitoring yang dilakukan dalam kegiatan pelatihan analisis data deksriptif dan inferensial, maka rekomendasi yang kami ajukan bagi kegiatan ini adalah: 1) Kegiatan serupa dapat dilaksanakan secara kontinyu untuk meningkatkan pengetahuan, pemahaman dan keterampilan mahasiswa dalam analisis data deskriptif dan inferensial, karena setiap tahun mahaiswa di setiap program studi akan melakukan kegiatan analisis data dalam menyelesaikan tugas kahir; 2) Kegiatan yang sama dapat dijadikan bagian dalam beberapa mata kuliah, seperti mata kuliah statistik dasar, evaluasi dan penilaian hasil belajar, serta pada mata kuliah metode penelitian.

\section{Output dan Outcome}

Output yang didapat dari kegiatan pengabdian masyarakat ini diantaranya adalah:1) Meningkatnya pengetahuan mahasiswa terhadap program exsel dan SPSS serta pemahaman mahasiswa terhadap kebermanfaatan program excel dan SPSS. 2) Meningkatnya pengetahuan dan keterampilan mahasiswa dalam mengoperasikan program microsoft excel serta memanfaatakannya sebagai sarana mengolah data. 3) Meningkatakan pengetahuan dan keterampilan serta menambah wawasan mahasiswa bagaimana mengolah data hasil penelitian menggunakan program SPSS. 4) Pengetahuan akan Teknik analisis data mengurangi kesalahan pengolahan data yang sering dilakukan mahasiswa.

Sedangkan Outcame yang didapatkan dari kegiatan pengabdian masyarakat ini adalah: 1) Melalui kegiatan pelatihan pemanfaatan Microsoft excel dan aplikasi SPSS, mahasiswa dapat mempercepat proses analisis data hasil penelitian yang akan dilakukan mahasiswa. Selain itu 
mahasiswa akan lebih mudah mempertanggungjawabkan hasil analisis data, meningkatkan kualitas hasil analisis data penelitian yang akan dilakukan mahasiswa, serta mempercepata proses bimbingan skripsi. 2) Bagi dosen pembimbing skripsi, kegiatan pelatihan pemanfaatan Microsoft excel dan aplikasi SPSS terhadap mahasiswa sekiranya dapat bermanfaat dalam kegiatan proses bimbingan skripsi terutama dalam memberikan koreksi pada bagian analisis data. 3) Bagi program studi dapat semakin mempercepat masa studi mahasiswa dan meningkatkan kualitas lulusan.

\section{Kesimpulan}

Berdasarkan hasil pengadian yang dilaksanakan dapat disimpulkan bahwa 1) Kegiatan pengabdian kepada masyarakat mengenai pelatihan peningkatan keterampilan analisis data statistik deskriptif dan statistik inferensial mahasiswa STKIP Weetebula dengan program excel dan aplikasi SPSS telah terlaksa dengan baik. Pelaksanaan kegiatan pengabdian mengenai pelatihan peningkatan keterampilan analisis data statistik deskriptif dan statistik inferensial mendapat tanggapan yang sangat baik dari mahasiswa peserta kegiatan.

\section{Ucapan Terima Kasih}

Terima kasih disampaikan kepada Lembaga Penelitian dan Pengabdian Kepada Masyarakat (LPPM) STKIP Weetebula atas dukungan dan kesempatan yang diberikan sehingga kegiatan pengabdian ini dapat terlaksana dengan baik sampai selesai. Atas partisipasi aktif mahasiswa yang menjadi subyek pengabdian juga disampaikan terimakasih.

\section{Daftar Pustaka}

Fauziah, Fenty dan Karhab, Rinda Sandaya. 2019. Pelatihan Pengolahan Data Menggunakan AplikasiSPSS Pada Mahasiswa. Jurnal Pesut: Pengabdian Untuk Kesejahteraan UmaT: Vol. 1 No. 2.

Febrilia, Setyawati. 2020. Workshop Pengolahan Data Menggunakan SPSS Bagi Mahasiswa Universitas Pendidikan Mandalika. MARTABE: Jurnal Pengabdian Masyarakat. Vol. 3, No. 2.

Helaluddin. 2019. Peningkatan Kemampuan Literasi Teknologi dalam Upaya Mengembangkan Inovasi Pendidikan di
Perguruan Tinggi. PENDAIS: Vol.1, No. 1, Hal: 44-45

Permana, R. S. M. dan J.N. Mahameruaji. 2019. Strategi Pemanfaatan Media Baru Net. TV. Jurnal Studi Komunikasi dan Media 23 (1): 21-36.

Putra, Zainal., dkk. 2018. Pelatihan Pengolahan Data Penelitian Dengan Software SPSS Bagi Mahasiswa Lintas Perguruan Tinggi Dalam Kabupaten Aceh Barat Provinsi Aceh. Jurnal ABDIMAS UNMER Malang. Vol. 3, Edisi Khusus.

Wicaksono, Yudhy. 2015. Panduan Lengkap Mengelola Data Excel Optimalkan Kemampaun Excel anda secara efektif, efisien, dan professional. Jakarta: PT Elex Media Komputindo. 